Prace Komisji Geografii Komunikacji PTG Transport Geography Papers of Polish Geographical Society

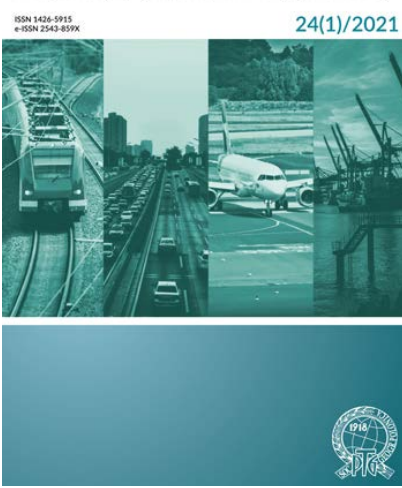

Transport Geography Papers of Polish Geographical Society

2021, 24(1), 44-56

DOI 10.4467/2543859XPKG.21.003.14946

\title{
COST-SUITABILITY LAND MODELING FOR CURRENT AND PROPOSED TRANSPORT INFRASTRUCTURE ALONG TIMIȘ-CERNA CORRIDOR (ROMANIA)
}

\section{Modelowanie terenu pod kq̨tem opłacalności dla obecnej i proponowanej infrastruktury transportowej wzdłuż korytarza Timiș-Cerna (Rumunia)}

\section{Beniamin Stoica-Fuchs (1), Bogdan-Andrei Michai (2), lonuț Săvulescu (3), Robert Dobre (4) \\ (1) Doctoral school "Simion Mehedinți-Nature and Sustainable Development", Faculty of Geography, University of Bucharest, Nicolae Bălcescu Boulevard, 1, 010401, Bucharest, Romania \\ e-mail: beniamin.stoica-fuchs@drd.unibuc.ro (corresponding author)}

(2) Department of Geomorphology, Pedology, and Geomatics, Faculty of Geography, University of Bucharest, Nicolae Bălcescu Boulevard, 1, 010401, Bucharest, Romania

e-mail: bogdanandrei0771@gmail.com

https://orcid.org/0000-0002-5834-8697

(3) Department of Geomorphology, Pedology, and Geomatics, Faculty of Geography, University of Bucharest, Nicolae Bălcescu Boulevard, 1, 010401, Bucharest, Romania

e-mail: savulescu@geo.unibuc.ro

https://orcid.org/0000-0001-6054-7954

(4) Department of Geomorphology, Pedology, and Geomatics, Faculty of Geography, University of Bucharest, Nicolae Bălcescu Boulevard, 1, 010401, Bucharest, Romania

e-mail: dobre@geo.unibuc.ro

https://orcid.org/0000-0002-0590-1700

\section{Citation:}

Stoica-Fuchs B., Mihai B., Săvulescu I., Dobre R., 2021, Cost-suitability land modeling for current and proposed transport infrastructure along Timiș-Cerna Corridor (Romania), Prace Komisji Geografii Komunikacji PTG, 24(1), 44-56.

\begin{abstract}
Cost-suitability land modeling is one of the mandatory conditions for the proposal of new transport development projects, in order to achieve optimal costs of design and construction. In the present study, we intend to present a model for assessing land suitability for current and proposed transport infrastructure along the Orient-East Med TEN-T Corridor, in the mountainous region of the Timiș-Cerna Corridor (Romania). The relevant factors for our analysis were outsourced from various thematic data sets and refer to lithology, morphological and morphometrical properties of landforms, soil characteristics and climatic setting of the study area. Conservation of natural environment and human habitat was also taken into consideration by means of analyzing land use patterns and spatial distribution of protected areas. The methodology is based on the principles of cartographic algebra and vector overlay analysis, currently implemented in various GIS applications. The results of our study aim for the identification of critical sectors along the current and proposed transport infrastructure, which intersect areas with high development cost and low suitability. Starting from our observations, specialists in transport networks and spatial planning could make use of dedicated computation algorithms to identify and describe optimal routes for future infrastructure projects that would connect the southern and western parts of the country.
\end{abstract}

Key words: land suitability, transportation networks, GIS analysis, current geomorphologic processes 


\section{Introduction}

Land suitability analysis is one of the necessary conditions for streamlining the design and construction of roads and railways (Belka, 2005). Internationally, this is currently an insufficiently researched field, given the complex nature of the issue. Current studies are focused on the analysis of public transport dynamics specific to urban environment or emphasize aspects related to accessibility (Bárta, 2020). Most studies based on multicriteria analyses performed in GIS environment use a cost model for assessing the opportunities for the development of transport networks, based on which various route options are subsequently proposed (Farooq et al., 2018, 2019; Li et al., 2021). The suitability factors generally refer to lithology, topography parameters such as elevation or slope angle and the current land use, complemented in some cases with features related to hydrological or geomorphological risks (Pu et al., 2021). In Romania, various assessments of land suitability for the development of transport infrastructure were conducted along the Prahova Corridor (Dobre, 2011; Dobre, 2016), in Ţara Bârsei (Purcăreață et al., 2015) and for the Brașov-Bacău expressway route (Paunescu et al., 2019). The main geographic factors of interest are related to lithology, slope inclination and land use, enhanced with aspects related to soil characteristics.

In the present study we intend to perform a land suitability analysis for the development of transport infrastructure along the TEN-T East-Med Transport Corridor, in the Timiș-Cerna Valley. The final goal of the analysis is to locate network segments that intersect areas of low suitability and high economic cost, which could translate into higher maintenance or development expenditures for current or proposed infrastructure projects. An element of uniqueness for our research, when considering previous studies carried out at national scale in this area, is given by the fact that land suitability will be expressed in units of cost for infrastructure development, as opposed to common land suitability grades. This choice is justified by the opportunity to use cost measurements in order to facilitate the integration of least-cost path algorithms for the design of alternative transport routes.

The Timiș-Cerna corridor is located in the southwest of Romania, between the Southern Carpathians (east) and the Banat Mountains (west). It is also delimited by the Danube river to the south, on the Romanian-Serbian border (Fig. 1). In order to capture

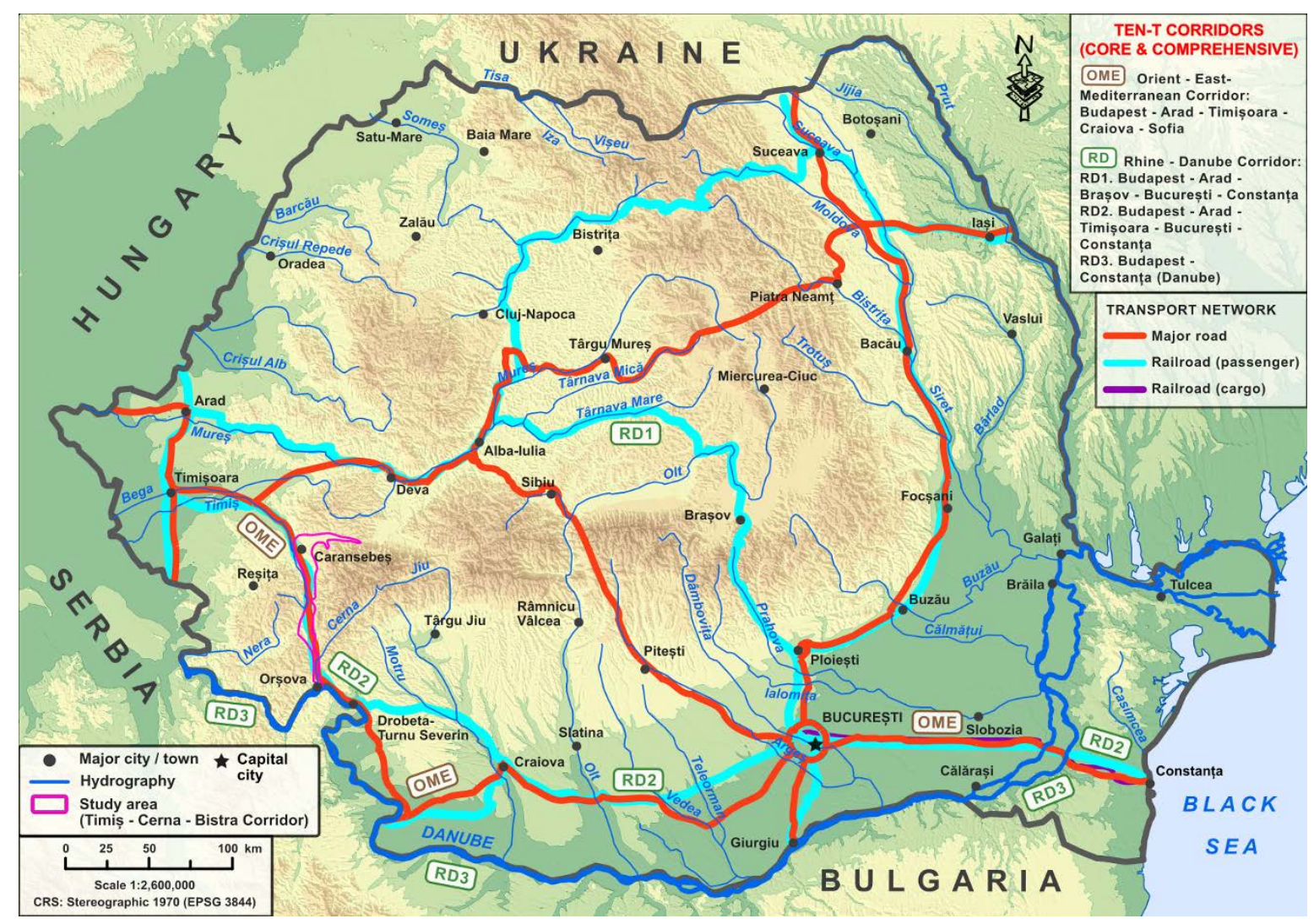

Fig. 1. Location of the study area (Timiș-Cerna Valley) on national scale, along main TEN-T European Transport Corridors (Core \& Comprehensive). 
the specific mountainous conditions, the study area has been extended east of Caransebeș, to the Iron Gate Pass of Transylvania. The environmental conditions are specific to a mountainous corridor, being favorable for the development of geomorphologic processes (landslides, rock falls) with significant impact on transport infrastructure. Between the municipalities of Caransebeș (north) and Orșova (south) has been developed a section of the Orient-East Med corridor, as part of the trans-European TEN-T network. Transport infrastructure consists of the European road E70 (91.3 $\mathrm{km}$ ) and the main railway 900 connecting Bucharest and Timișoara, mainly used for passenger transport. Apart from these, there are a few national (DN68, DN57 and DN57B) and county roads, along with a segment of the Caransebeș-Subcetate secondary railway, which is currently decommissioned. and soil characteristics were extracted from specific topographic and thematic maps. Temperatures were obtained by processing the WorldClim 2.1 data set, while boundaries of protected areas and proposed routes for future infrastructure projects were provided by respective national agencies. The current transport network was acquired through vectorization from the Topographic Map of Romania, scale 1: 50,000 (Fig. 2).

In order to build the land cost-suitability map, the required data sets were converted into raster formats and resampled at a common spatial resolution of $30 \mathrm{~m}$. To facilitate overlay analysis with the transport network, the cost-suitability surface was later converted to vector format. By using the Intersect function (Analysis Tools) in ArcGIS Desktop, we were able to identify road and railway alignments located in areas with high and very high cost for development.

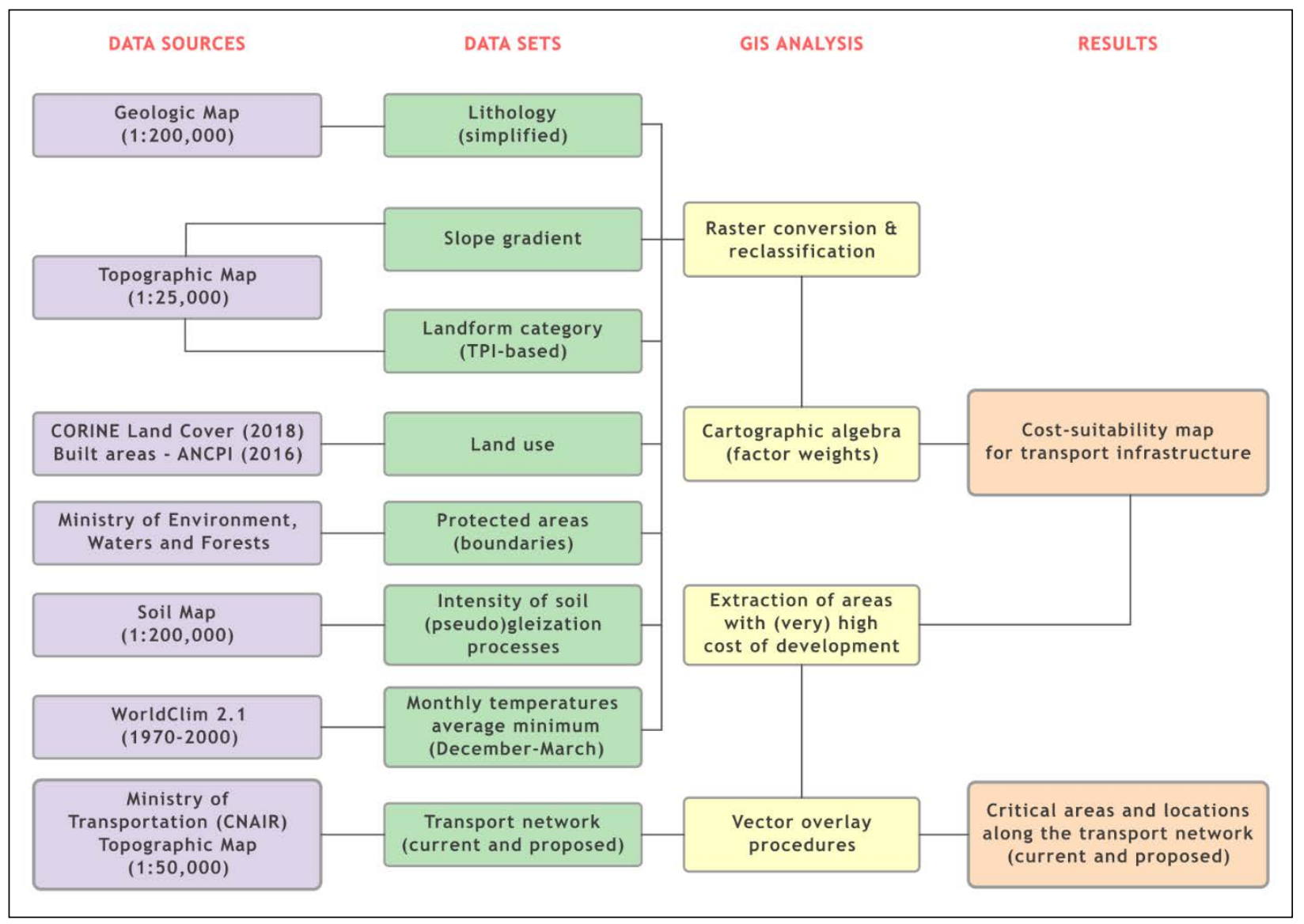

Fig. 2. Proposed methodology for land cost-suitability multicriterial analysis.

Source: own elaboration.

\section{Datasets and Methodology}

The data sets used for multicriterial analysis were harvested from a wide range of thematic sources. Land use data was acquired from CORINE Land Cover 2018, while information on land morphology, lithology
Classification of environmental factors according to their suitability for the development of transport infrastructure was performed in two stages. First, suitability marks were granted for each value class of each relevant factor. These grades were ranged between 0 and 10 , where 0 represents minimum favorability 
and 10 is the maximum degree of suitability for the development of transport routes. These grades were chosen according to the specificity of the study area, the amplitude of parameter values, but also based on information collected from review literature representative for such multicriterial analysis. Subsequently, these values were standardized on a scale from 0 to 100 , in order to quantify the cost of development for the transport network along certain land typologies.

The conversion of suitability marks into cost grades was achieved with the following equation:

$$
X_{i j}^{\prime}=\left(1-\left(\frac{X_{i j}-X_{j}^{\text {min }}}{X_{j}^{\text {max }}-X_{j}^{\text {min }}}\right)\right) \times 100
$$

where: $X_{i j}^{\prime}$ is the cost associated with a single value class of a factor; is the suitability grade of a single value class pertaining to a factor; $X_{j}^{\text {min }}$ represents the minimum value of the entire suitability grade series for a single factor; $X_{j}^{\max }-X_{j}^{\min }$ is the amplitude of values from an entire suitability grade series associated with a single relevant factor.

Modeling land cost-suitability for the development of transport infrastructure with consideration to appropriate geographical factors was achieved by calculating a cumulative cost area using cartographic algebra. Specific weights were assigned to each environmental factor, based on their relative importance. The following equation was used to generate the final cost-suitability surface: evant factors. Finally, soil and climate characteristics received the lowest weightage, being considered factors of local significance for the development of transport infrastructure.

\section{Relevant cost-suitability factors}

\subsection{Lithology}

Considering the lithological factor, the Timiș-Cerna Corridor features a great variety of typologies. The lithology specific to each geological age has been simplified and reclassified in 8 specific categories, depending on suitability for the transport network (Fig. 3, Tab. 1).

The most favorable areas are located along the floodplains of Timiș, Bistra and Cerna rivers, in areas where soft sedimentary rocks (gravels, sands, loess deposits) are prevalent. These expand upon $25 \%$ of the corridor.

Regions of average cost occupy the most significant part of the corridor (36\%), being mostly located on its mountainous periphery and consisting of metamorphic and igneous formations, along with hard sedimentary rocks (limestone, dolomite).

Regions featuring the highest cost for transport infrastructure (7\%) are characterized by the presence of friable sedimentary rocks in association with clays and shales. Slope instability is enhanced by high geodeclivity values and the presence of erosionspecific landforms (gullies, ravines, torrents), which render the development of high-speed transport routes ineffective.

$$
S C=\frac{(C L \times 15)+(C P \times 20)+(C U M \times 15)+(C U T \times 20)+(C A P \times 15)+(C S \times 10)+(C T M \times 5)}{100}
$$

where: $\mathrm{SC}$ is the cumulative cost area for the entire corridor; $\mathrm{CL}$ is the cost area for lithology; $\mathrm{CP}$ is the cost derived from geodeclivity; CUM is the cost associated with landform units; CUT is the cost associated with various land use typologies; CAP is the expression of development cost across protected areas; $\mathrm{CS}$ is the development cost based on soil characteristics; CTM is the expression of cost according to the climatic component.

Geological and geomorphological factors were awarded the highest weights for the cost-suitability model, as they are considered to have the most importance in the process of desgining and developing transportation routes (Mihai, Dobre, Săvulescu, 2014). The requirements for environmental protection and conservation of high-value land typologies were also reflected in the importance granted to respective rel-

\subsection{Slope angle}

Slope angle has an extremely important role in ensuring the dynamics of geomorphological processes. We defined 6 classes of geodeclivity which were assigned appropriate values of cost and suitability. Slope angle values were derived using a Digital Elevation Model (DEM) and averaged using a rectangular matrix filter with a $3 \times 3$ cell neighbourhood $(100 \mathrm{~m})$, in order to eliminate any errors of the elevation surface.

Slope angle intervals specific to low and very low costs are representative for $42 \%$ of the corridor, while areas of high and very high development cost for transport infrastructure are specific for $27 \%$ of the study area (Fig. 3, Tab. 1).

The highest geodeclivity values are located on the mountainous borders of the corridor, but also 
in the southern part of the study area (Orșova Corridor), increasing the development costs for transport infrastructure projects in that area. Lands with high suitability were mostly located in the lower floodplains of Timiș and Bistra rivers.

\subsection{Landform category}

The geomorphological location of an area could have a very important influence on land suitability for the development of transport infrastructure. Lower parts of valleys, represented by floodplains and terraces, are preferable in comparison to slopes or ridges, which are typically characterized by steeper terrain and higher morphodynamic potential.

Landform category was therefore chosen as an important factor related to land suitability for infrastructure projects. Landform classification was conducted using topographic position index (TPI), which uses relative elevation of raster cells from a digital terrain model. Based on a neighborhood radius of $1500 \mathrm{~m}$ and slope values we obtained 6 distinct landform categories, namely: valleys, lower slopes, gentle slopes, steep slopes, upper slopes and ridges.

Steep slopes (39\%) are prevalent in the study area along with lower slopes (22\%), mainly located along Timiș and Bistra rivers. Valleys and lower slopes were awarded maximum favorability, while gentle and steep slopes received significantly lower suitability grades (8 and 6 , respectively). Finally, upper slopes and ridges were granted the lowest suitability values (Fig. 3, Tab. 1).

\subsection{Land use}

Land use was processed based on the information acquired from the European Corine Land Cover 2018 data set. The initial 19 land use typologies were reclassified into 8 distinct categories: forests $(40 \%)$, agricultural land (20\%), meadows (20\%), orchards (10\%), shrubland (4\%), built-up areas (3\%), wetlands and unproductive land. In order to integrate aspects related to the expansion of residential areas and the requirements for good "sound insulation" along transport routes, we improved the initial data set by adding more detailed boundaries of built-up areas, acquired from ANCPI (National Agency for Cadastre and Land Publicity). This process was performed using the Update (Data Management) function in ArcGIS Desktop. The result featured an increase in land classified as built-up areas by approx. $35 \mathrm{~km}^{2}$ and a decrease of agricultural land by $22 \mathrm{~km}^{2}$.

Built-up areas and wetlands have received the lowest suitability grades, as high-speed transport infrastructure typically avoids human habitat and surfaces with high groundwater levels. Featuring high economic value, agricultural land and orchards were granted poor suitability grades. Forests, shrubland and meadows were awarded higher favorability scores, considering the fact that they do not typically represent restrictive land use categories for the development of transport networks. Shrubland and unproductive land were granted the highest suitability grades, corresponding to the lowest development cost (Fig. 3, Tab. 1).

\subsection{Protected areas}

Protected areas were classified into 5 cost-suitability categories, based on existing regulations. National and natural parks, along with Ramsar sites, were granted the lowest suitability grades. On the other hand, protected areas of local or regional interest received the highest suitability values. For Natura 2000 sites we opted for average favorability grades, as development of transport routes could be justified if appropriate engineering solutions were employed in order to mitigate their impact on protected habitats and species. To resolve geometric conflicts between overlapping typologies of protected areas, cartographic algebra was used to extract the highest corresponding cost values. For instance, a land classified simultaneously as national park ("Domogled-Valea Cernei" National Park), Natura 2000 Special Protection Area (SPA) and protected area of local importance, received the highest available cost of development, corresponding to the typology of national park. We also performed overlay analysis for the extraction of areas without protection restrictions, using the Erase (Data Management) function in ArcGIS Desktop. The resulted land surface was awarded the highest suitability value for transport development (Fig. 4, Tab. 1).

\subsection{Soil characteristics}

Timiș-Cerna Corridor is marked by the presence of three soil classes - Cambisols (43\%), Luvisols (39\%) and Protisols (17\%), according to the 2012 Romanian Soil Taxonomy System.

In order to determine soil suitability for transport infrastructure we analyzed the distribution of pedogenetic gleization and pseudogleization processes. These could require special engineering measures and involve increasing development costs in order to eliminate excess humidity. Gleization assumes permanent existence of water excess, while pseudogleization requires only an intermittent humidity surplus, controlled by rainfall regime and local geomorphological conditions. 

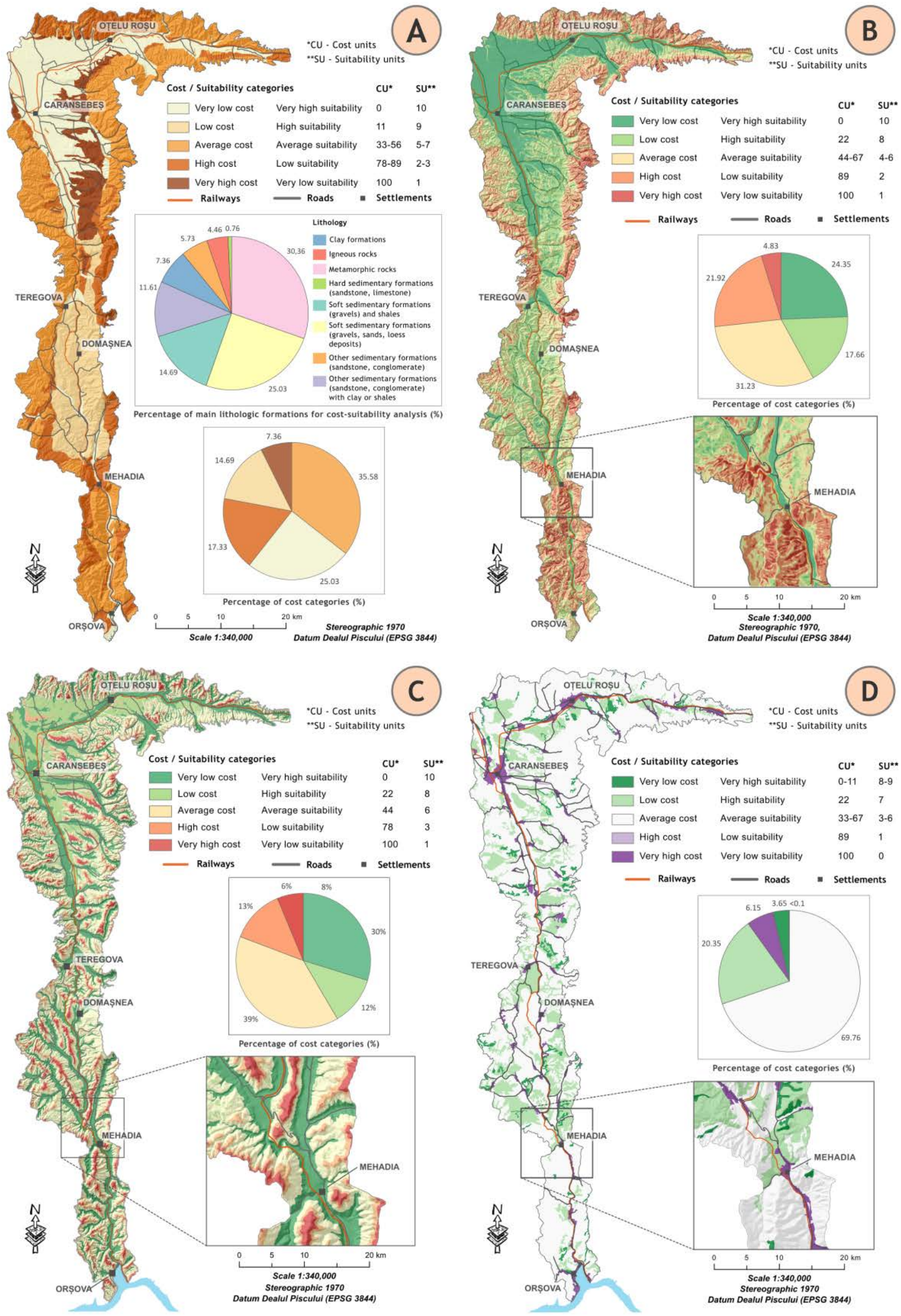

Fig. 3. Cost-suitability maps for relevant factors used in multicriterial analysis

(A - Lithology; B - Slope angle; C - Landform category; D - Land use).

Source: own elaboration. 

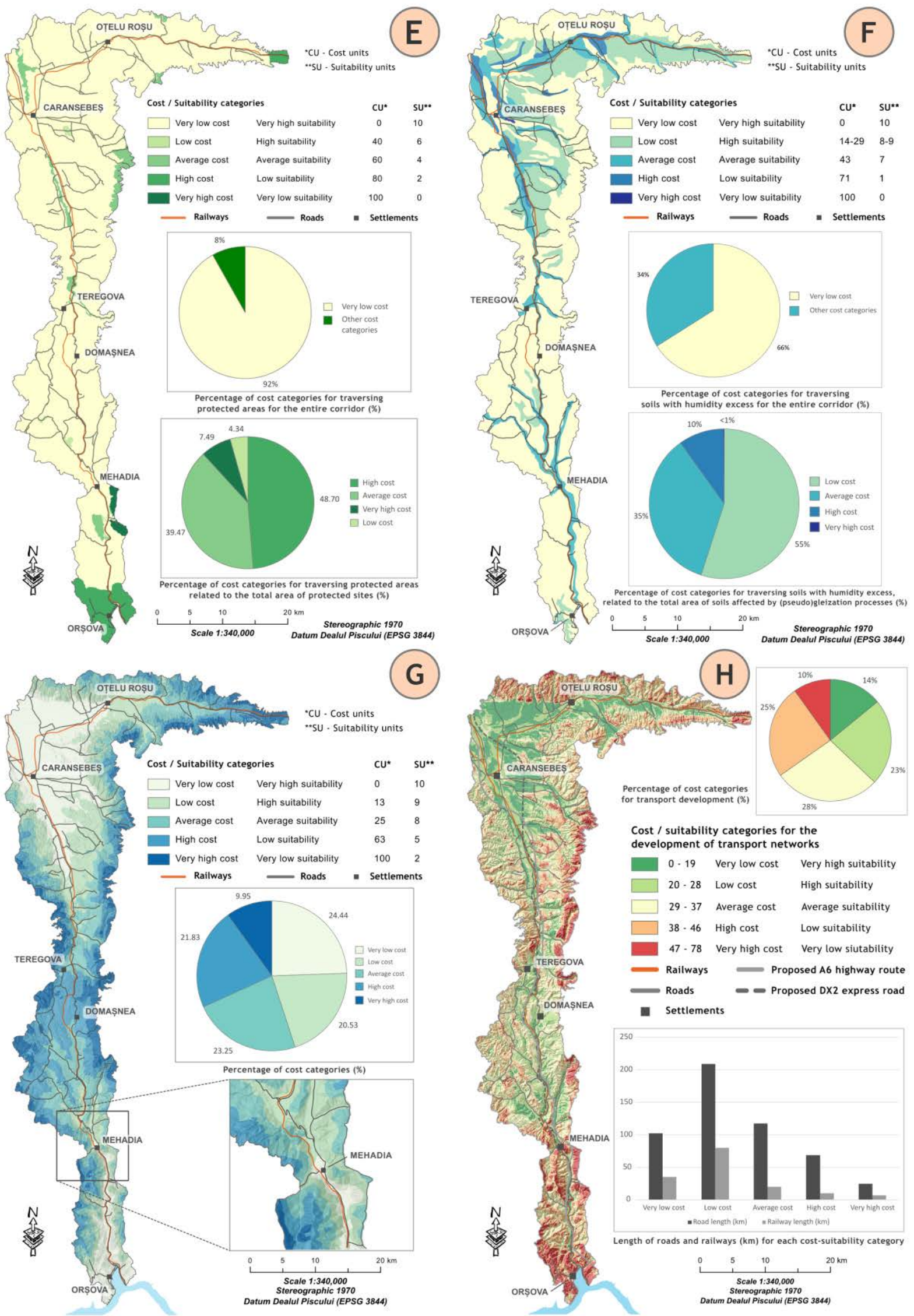

Fig. 4. Cost-suitability maps for relevant factors used in multicriterial analysis ( $\mathrm{E}$ - Protected areas; $\mathrm{F}$ - Soil characteristics; $\mathrm{G}$ - Climatic factor) and final cost-suitability map (H).

Source: own elaboration. 
Lands unaffected by excess moisture received maximum suitability scores. Areas affected by pseudogleization received grades ranging between 7 and 9 , while those affected by gleization were awarded scores between 3 and 7, depending on the intensity of each pedogenetic process. Lands most affected by excess moisture are located in the proximity of important rivers, especially along the floodplains of Timiș and Bistra rivers. About 22\% of soils are affected by pseudogleization processes and $12 \%$ feature permanent humidity excess (Fig. 4, Tab. 1).

\subsection{Climatic factor}

The climatic factor is particularly important for shaping current geomorphological processes. Thermal amplitudes determine the frequency and intensity of rock weathering, which directly translates into the lifespan of roadways and railway tracks, but also in slope-related morphodynamic processes (rock falls, landslides). Temperatures could also influence the occurrence of meteorological risk events, such as sleet, frost or rime. These could impose local speed restrictions or temporarily halt traffic in order to ensure the safety of participants.

Considering the close relationship between elevation and the variability of meteorological indicators, we decided to use the minimum monthly temperatures $\left({ }^{\circ} \mathrm{C}\right)$ of the coldest four months of the year as a relevant factor. These were acquired from the WorldClim 2.1 grids, at the spatial resolution of 30 arc seconds (Fick, Hijmans, 2017). Temperature values were resampled using Kriging interpolation and were divided in 5 suitability classes (Fig. 4, Tab. 1).

Areas of high temperature $\left(-1.3--3.0^{\circ} \mathrm{C}\right)$ received high suitability scores, considering the fact that most transport routes are located along them. Severe grading penalties were applied for subsequent classes, considering the higher probability for the occurrence of meteorological risk events.

Tab. 1. Suitability and cost values for relevant factors used in multicriterial analysis.

\begin{tabular}{|c|c|c|c|}
\hline Relevant factors & Specific typologies & $\begin{array}{l}\text { Suitability } \\
\text { grade }\end{array}$ & Cost grade \\
\hline \multirow{8}{*}{ Lithology } & $\begin{array}{l}\text { Soft sedimentary formations (gravels, sands, loess } \\
\text { deposits) }\end{array}$ & 10 & 0 \\
\hline & Soft sedimentary formations (gravels) and shales & 9 & 11 \\
\hline & Metamorphic rocks & 7 & 33 \\
\hline & Hard sedimentary formations (sandstone, limestone) & 6 & 44 \\
\hline & Igneous rocks & 5 & 56 \\
\hline & $\begin{array}{l}\text { Semi-hard sedimentary formations (sandstone, } \\
\text { conglomerate) }\end{array}$ & 3 & 78 \\
\hline & $\begin{array}{l}\text { Semi-hard sedimentary formations (sandstone, } \\
\text { conglomerate) with clay or shales }\end{array}$ & 2 & 89 \\
\hline & Clay formations & 1 & 100 \\
\hline \multirow{6}{*}{ Slope angle } & $0^{\circ}-5^{\circ}$ & 10 & 0 \\
\hline & $5^{\circ}-10^{\circ}$ & 8 & 22 \\
\hline & $10^{\circ}-15^{\circ}$ & 6 & 44 \\
\hline & $15^{\circ}-20^{\circ}$ & 4 & 67 \\
\hline & $20^{\circ}-30^{\circ}$ & 2 & 89 \\
\hline & $>30^{\circ}$ & 1 & 100 \\
\hline \multirow{6}{*}{ Landform category } & Valleys & 10 & 0 \\
\hline & Lower slopes & 10 & 0 \\
\hline & Gentle slopes & 8 & 22 \\
\hline & Steep slopes & 6 & 44 \\
\hline & Upper slopes & 3 & 78 \\
\hline & Ridges & 1 & 100 \\
\hline
\end{tabular}




\begin{tabular}{|c|c|c|c|}
\hline Relevant factors & Specific typologies & $\begin{array}{l}\text { Suitability } \\
\text { grade }\end{array}$ & Cost grade \\
\hline \multirow{8}{*}{ Land use } & Built-up areas & 0 & 100 \\
\hline & Wetlands & 1 & 89 \\
\hline & Agricultural land & 3 & 67 \\
\hline & Orchards & 4 & 56 \\
\hline & Forests & 6 & 33 \\
\hline & Meadows & 7 & 22 \\
\hline & Shrubland & 8 & 11 \\
\hline & Unproductive land & 9 & 0 \\
\hline \multirow{7}{*}{ Protected areas } & National park & 0 & 100 \\
\hline & Wetlands of international importance (Ramsar sites) & 2 & 80 \\
\hline & Natural park & 2 & 80 \\
\hline & Natura 2000 - Special Protection Area (SPA) & 4 & 60 \\
\hline & Natura 2000 - Site of Community Importance (SCI) & 4 & 60 \\
\hline & Unclassified protection (local or regional importance) & 6 & 40 \\
\hline & Land with no restriction & 10 & 0 \\
\hline \multirow{7}{*}{$\begin{array}{c}\text { Soil characteristics (intensity } \\
\text { of gleization-pseudogleization } \\
\text { processes) }\end{array}$} & None - None & 10 & 0 \\
\hline & None - Reduced & 9 & 14 \\
\hline & None - Moderate & 8 & 29 \\
\hline & None - Strong & 7 & 43 \\
\hline & Reduced - None & 7 & 43 \\
\hline & Moderate - None & 5 & 71 \\
\hline & Strong - None & 3 & 100 \\
\hline \multirow{5}{*}{$\begin{array}{l}\text { Climatic factor (Min. monthly } \\
\text { temperatures, Dec.- March) }\end{array}$} & $-1.3--2.3^{\circ} \mathrm{C}$ & 10 & 0 \\
\hline & $-2.4--2.9^{\circ} \mathrm{C}$ & 9 & 13 \\
\hline & $-3.0--3.4^{\circ} \mathrm{C}$ & 8 & 25 \\
\hline & $-3.5--3.9^{\circ} \mathrm{C}$ & 5 & 63 \\
\hline & $-4.0--5.4^{\circ} \mathrm{C}$ & 2 & 100 \\
\hline
\end{tabular}

Source: own elaboration.

\section{Results}

Development cost inversely reflects suitability for the development of transport infrastructure. High-cost areas correspond to low-suitability land, while lowcost regions are more favorable for the development of the transport network.

Areas with high development cost are characterized by a lithological substrate composed of either clay formations or semi-hard sedimentary rocks (sandstones, conglomerates) mixed with clays or shales, being located on upper slopes or ridges with slope angles exceeding $15-20^{\circ}$. Typical land use scenarios include built-up areas, wetlands or agricultural land, while the presence of an important protected area (Ramsar site, national or natural park) could also increase the development cost for infrastructure projects. Soils affected by moderate or strong gleization processes and high elevation, corresponding to minimum monthly temperatures below $-3.5^{\circ} \mathrm{C}$, also decrease land suitability.

Areas with low development cost are specific to lands with either soft sedimentary substrate (gravels, 
sands) or hard metamorphic formations, along valleys with lower or gentle slopes and with slope angles typically below $10^{\circ}$. Low economic value of shrubland, meadows and unproductive areas also increases their suitability for infrastructure development. Lack of restrictions related to protected areas of national or international importance and the presence of soils uninfluenced or mildly affected by humidity excess further contribute to maintaining a high development potential.

Lands characterized by very low development cost (0-19) extend over $14 \%$ of the study area, being located mainly along the floodplains of Timiș and Bistra rivers, outside built-up areas, on surfaces with
GIS overlay analysis. Thus, we identified five potentially vulnerable regions along current and proposed routes (Fig. 5).

The first section of interest (Fig. 5, region A) is located on the southern border of the study area, close to the Danube. The proposed A6 motorway and DX2 express routes, along with the E70 European road and the main railway cross land with extremely low suitability located in this area (Fig. 6). West of Orșova, national road DN57 also passes through a hilly area featuring active morphodynamic processes, a fact indicated by its sinuous route.

A second difficult region in terms of land suitability (Fig. 5, region B) was identified north of Mehadia (Fig.6).

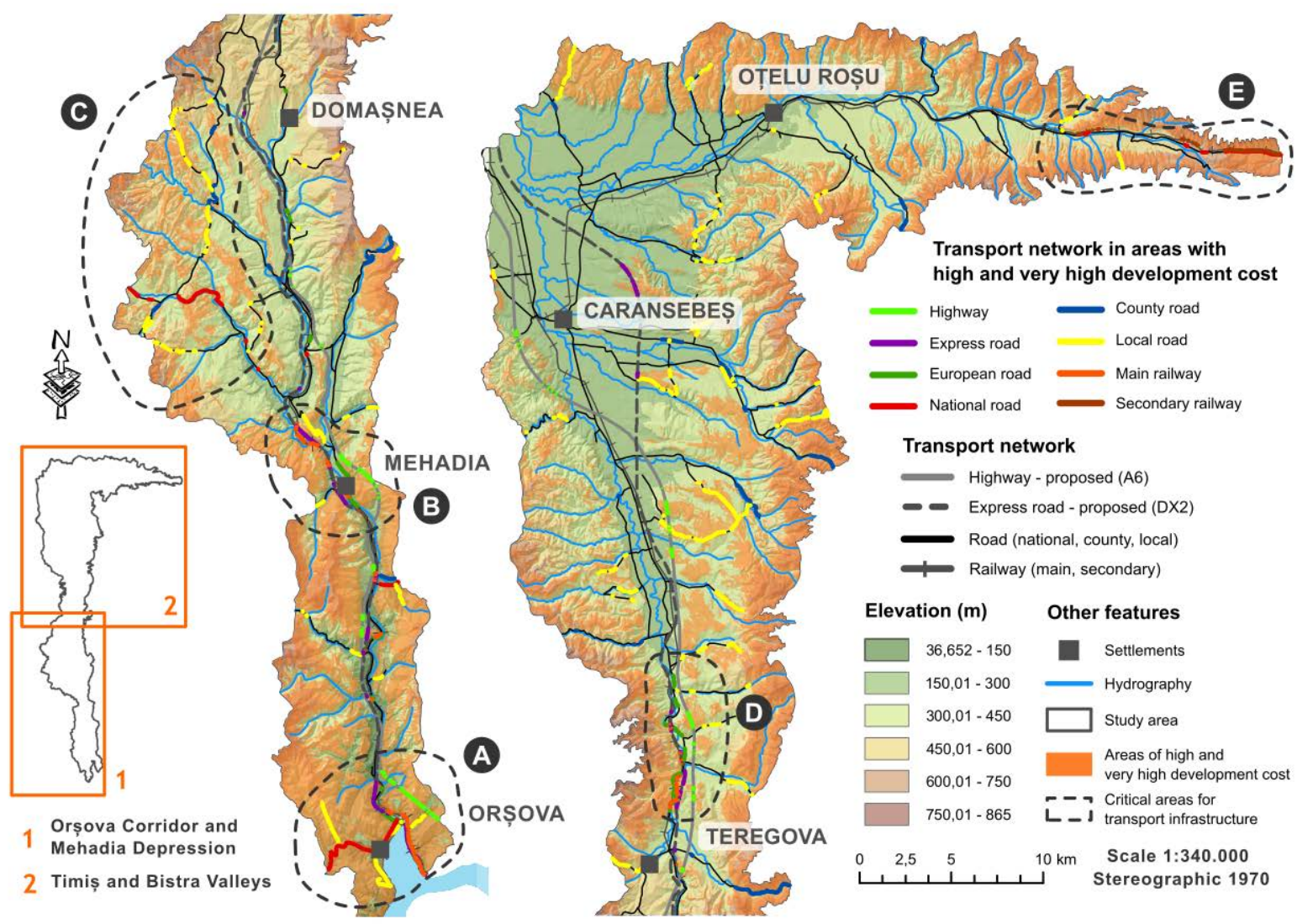

Fig. 5. Sections of transport network located in areas of high and very high development cost for infrastructure.

Source: own elaboration.

low slope angles. Areas of low development cost (2028) concentrate most of the transport infrastructure ( $40 \%$ of roads and $53 \%$ of railways), although they expand over just $23 \%$ of the study area. High (38-46) and very high (47-78) cost land extends significantly over the corridor (35\%), being located on its southern, eastern and northern mountainous periphery (Fig. 4).

In order to research the relationship between the transport network and land characterized by high and very high development cost we performed advanced
Here, both the A6 highway and the DX2 express road pass through a difficult rugged area, across steep slopes on either side of the settlement. The main railway also features a section affected by landslides, close to the geomorphological reservation of "The Black Ravine" ("Râpa Neagră").

Another area of interest in terms of land suitability is located in the western part of the study area (Fig. 5 , region C). National road DN57B intersects an area with active rock falls and detachments along slopes from the Globe's Canyon ("Cheile Globului"). 


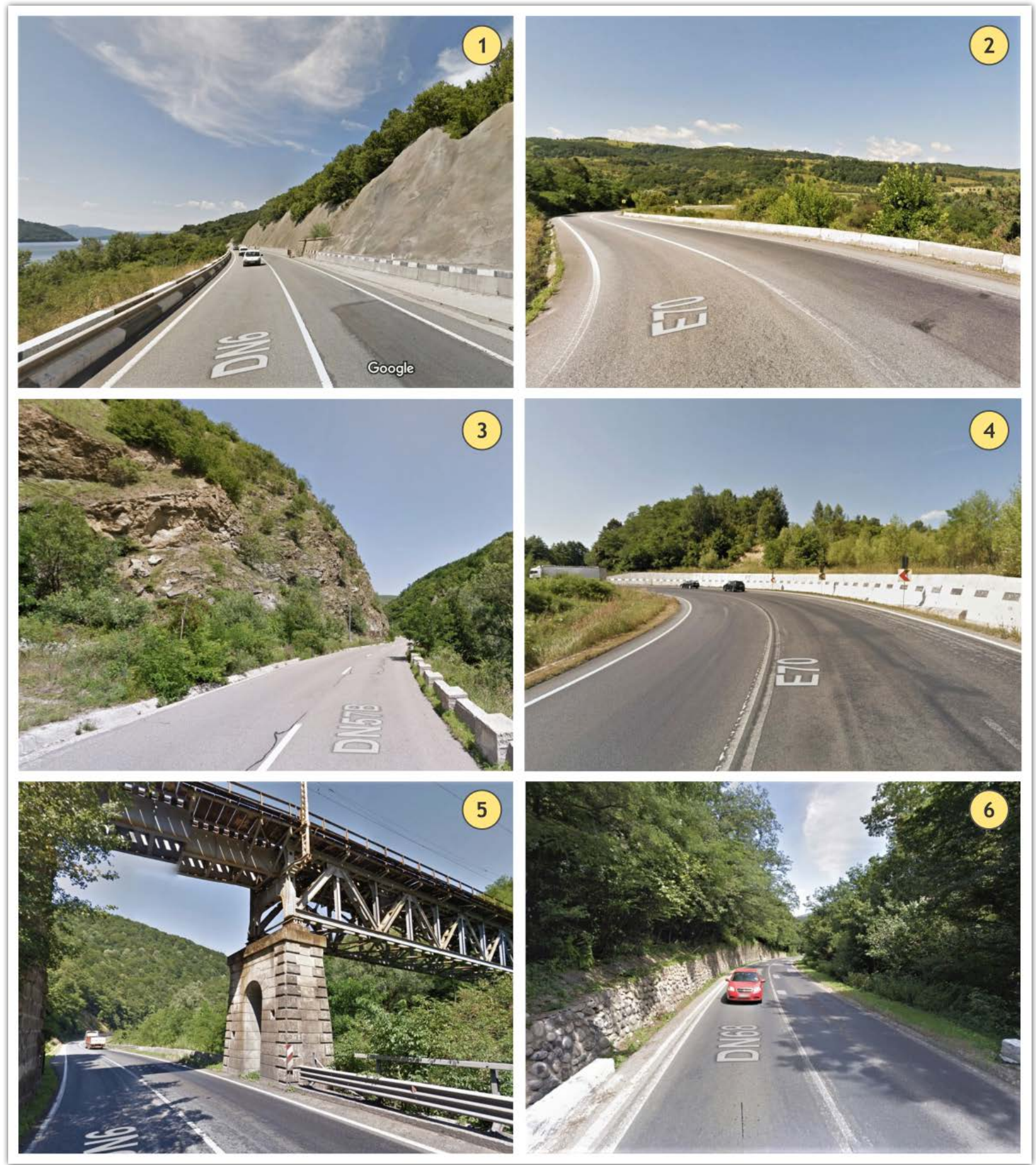

Fig. 6. Road and railway sections along low suitability areas for transport infrastructure. 1. Region A - E70 near Orșova (left side of the Danube); 2. Region B - E70 north of Mehadia; 3. Region C - DN57B in "Globe's Canyon"; 4 . Region D - E70 in Teregova Canyon; 5. Region D - E70 and main railway in Armenis Canyon; 6. Region E - DN68 in the Iron Gates of Transylvania Pass.

Source: Google Street View (July 2018-August 2019.

The fourth vulnerable area for transport infrastructure is located north of Teregova (Fig. 5, region D). This region is particularly difficult for railway infrastructure, along the Teregova and Armeniș Canyons created by Timiș river (Fig. 6). The E70 European road is also affected by slope instability and the occurrence of specific gravitational processes (small landslides, debris flow, rock falls).
The last region consisting of low-suitability land is located in the north-eastern part of the study area (Fig. 5, region E), where the secondary Caransebeș Subcetate railway features a series of critical sections as it passes through the Iron Gates of Transylvania $(700 \mathrm{~m})$. This low-suitability area is also transited by national road DN68, which is protected from slope 
instability by stone walls, featuring transverse drains for discharging run-off water (Fig. 6).

In order to further elaborate on the matter of critical regions for transport infrastructure, we located a series of critical sections corresponding to network segments with continuous lengths greater than $500 \mathrm{~m}$ (Tab. 2).

Critical points are spatially distributed according to regions previously identified and described (Fig. 7). For instance, the proposed A6 highway route features two critical sections east of Orșova $(1,6)$, two near Mehadia $(2,3)$ and three critical locations north of Teregova $(4,5,7)$. Considering the DX2 express road project, we identified three critical sections in the southern part of the study area $(8,11,13)$, two critical points close to Mehadia $(9,10)$ and one critical point located north-east of Caransebeș (12).

Furthermore, 7 critical sections were identified along the main railway: three located near Orșova

Tab. 2. Parameters of road and railway sections with length $>500 \mathrm{~m}$, located on land with high and very high development cost for transport infrastructure.

\begin{tabular}{|l|r|r|r|r|r|r|}
\hline $\begin{array}{c}\text { Transport network } \\
\text { typology }\end{array}$ & $\begin{array}{c}\text { Total length } \\
(\mathbf{m})\end{array}$ & $\begin{array}{c}\text { Average length } \\
(\mathbf{m})\end{array}$ & $\begin{array}{c}\text { Maximum length } \\
(\mathbf{m})\end{array}$ & $\begin{array}{c}\text { Minimum length } \\
(\mathbf{m})\end{array}$ & $\begin{array}{c}\text { No. of } \\
\text { sectors }\end{array}$ & $\begin{array}{c}\text { Average } \\
\text { development cost }\end{array}$ \\
\hline Highway & $6,374.52$ & 910.65 & $1,727.88$ & 603.48 & 7 & 44.64 \\
\hline Express road & $4,205.30$ & 700.88 & $1,019.62$ & 544.98 & 6 & 49.67 \\
\hline European road & $4,714.81$ & $1,178.70$ & $2,160.47$ & 612.97 & 4 & 52.79 \\
\hline National road & $10,839.95$ & $1,204.44$ & $2,871.58$ & 679.44 & 9 & 50.19 \\
\hline County road & $7,615.81$ & $1,087.97$ & $2,611.68$ & 517.10 & 7 & 41.72 \\
\hline Main railway & $6,122.74$ & 874.68 & $1,397.03$ & 552.25 & 7 & 49.77 \\
\hline Secondary railway & $3,676.92$ & $1,225.64$ & $2,244.29$ & 504.94 & 3 & 44.10 \\
\hline Local road & $25,511.74$ & 981.22 & $2,641.44$ & 505.46 & 26 & 43.74 \\
\hline Total / Average & $\mathbf{6 9 , 0 6 1 . 7 9}$ & $\mathbf{1 , 0 0 0 . 9 0}$ & $\mathbf{2 , 8 7 1 . 5 8}$ & $\mathbf{5 0 4 . 9 4}$ & $\mathbf{6 9}$ & $\mathbf{4 6 . 1 4}$ \\
\hline
\end{tabular}

Source: own elaboration.

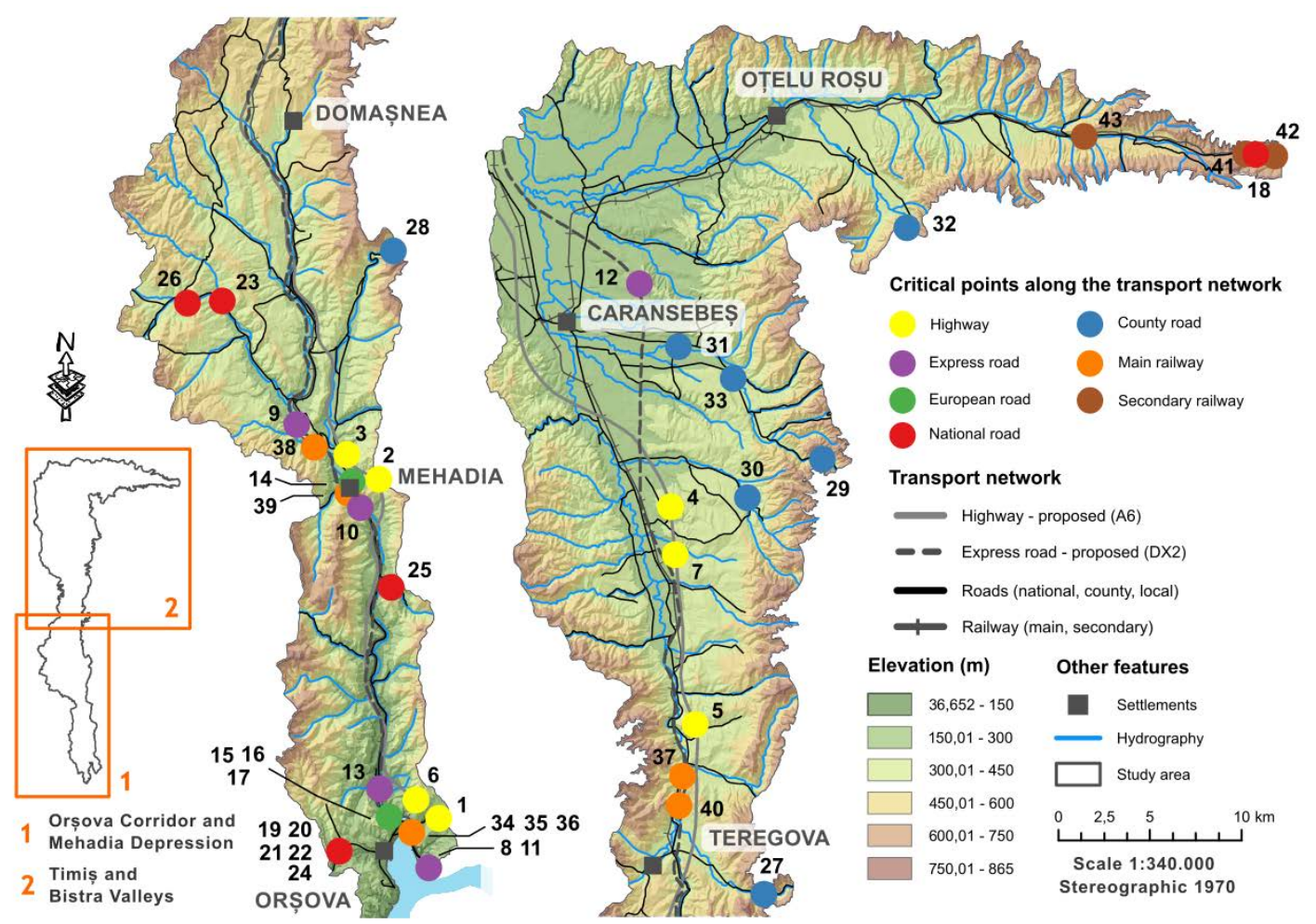

Fig. 7. Critical points representing road and railway sections with length $>500 \mathrm{~m}$, located in areas of high and very high development cost for transport infrastructure.

Source: own elaboration. 
$(34,35,36)$, two near Mehadia $(38,39)$, along with two more inside the Teregova and Armeniș Canyons (37, 40). For the secondary Caransebeș - Subcetate railway, our analysis showcased three critical points $(41,42,43)$.

\section{Discussion}

Considering the current state of research on land suitability for transport infrastructure, our study features a few innovative aspects. First, previous methodologies have been extended by integrating data concerning landform typology and the elevation-related climatic factor, in order to better emphasize the importance of relief for designing transport routes. The requirements for habitat and biodiversity conservation, depending on the typology of protected areas, was also considered in our model.

Another element of novelty insufficiently explored in research literature consists of the identification, description and validation of regions with transport sectors located on low-suitability land. By means of GIS analysis we were able to obtain not only descriptive information concerning these critical areas, but also cost-related quantitative elements which could facilitate comparative analysis between regions of similar geographic characteristics.

Furthermore, the conversion of suitability factors into cost units, as demonstrated by Belka (2005), could be detailed through in-depth studies in order to identify optimal transportation routes in terms of environmental cost. The general applicability for both road and railway infrastructure, although a strong asset for the purpose of our study, could also be considered an important disadvantage. In order to propose new high-speed transport routes, our multicriterial analysis model requires specific calibration. This could be achieved by alignment with technical requirements of target infrastructure typologies, which may refer to geometric elements (minimum curvature radii), landscape-related aspects (achieving good visibility) or ensuring land stability under extreme geotechnical conditions (earthquakes).

\section{Conclusion}

Cost-suitability analysis is a useful tool for providing a preliminary picture of geographic conditions that restrict or favor the development of new transport routes. The proposed methodology could be a starting point for more detailed research, performed by means of feasibility studies. Such an approach could significantly reduce planning and maintenance costs associated with transport networks. It is therefore necessary for new infrastructure projects to be designed according to current geomorphologic conditions and aligned to legislative regulations specific to various typologies of protected areas. This would ensure both the long-term sustainability of land use and economic efficiency of proposed routes, along with adequate conservation of biodiversity and valuable geographic landscapes.

\section{References}

Bárta M., 2020, Comparative analysis of the accessibility and connectivity of public transport in the city districts of Krakow, Prace Komisji Geografii Komunikacji PTG, 23(3), 7-14.

Belka K., 2005, Multicriteria analysis and GIS application in the selection of sustainable motorway corridor, https:// doi.org/10.13140/2.1.4376.0322

Dobre R., 2016, Relația dinamica reliefului - infrastructura de transport, Editura Etnologică, București.

Farooq A., Xie M., Stoilova S., Ahmad F., 2019, Multicriteria Evaluation of Transport Plan for High-Speed Rail: An Application to Beijing-Xiongan, Mathematical Problems in Engineering, 2019, 1-23. https://doi. org/10.1155/2019/8319432

Farooq A., Xie M., Stoilova S., Ahmad F., Guo M., Williams E. J., Mahamat Issa A., 2018, Transportation Planning through GIS and Multicriteria Analysis: Case Study of Beijing and XiongAn, Journal of Advanced Transportation, 2018, 1-16. https://doi.org/10.1155/2018/2696037

Fick S. E., Hijmans R. J., 2017, WorldClim 2: New 1- km spatial resolution climate surfaces for global land areas, International Journal of Climatology, 37(12), 4302-4315. https://doi.org/10.1002/joc.5086

Li L., Zhu G., Wu D., Xu H., Ma P., Liu J., Wu P., 2021, Land suitability assessment for supporting transport planning based on carrying capacity and construction demand, PLOS ONE, 16(2), e0246374. https://doi.org/10.1371/ journal.pone.0246374

Mihai B., Dobre R., Săvulescu I., 2014, Geomorphotechnical Map for Railway Mainline Infrastructure Improvement. A case study from Romania. Géomorphologi : Relief, Processus, Environnement, 20(1), 79-90. https://doi. org/10.4000/geomorphologie.10525

Paunescu C., Dobre R., Draghici T., 2019, Multi-criteria analysis for major road infrastructure projects. Case study: Brașov - Bacău Highway, GeoPatterns, 4, 40-44. https://doi.org/10.5719/GeoP.4/5

Pu H., Xie J., Schonfeld P., Song T., Li W., Wang J., Hu J., 2021, Railway Alignment Optimization in Mountainous Regions Considering Spatial Geological Hazards: A Sustainable Safety Perspective, Sustainability, 13(4), 1661. https:// doi.org/10.3390/su13041661

Purcăreață G. I., Bogdan M., Dobre R., 2015, A model of land suitability general analysis for new infrastructure projects in the Bârsa country (Romania), Forum Geografic, XIV(1), 51-63. https://doi.org/10.5775/fg.2067-4635.2015.157.i 